\title{
金属イオン置換型イオン交換樹脂による水, アンモニアおよびオレフィンの吸着
}

(1976 年 8 月 19 日受理)

上松敬 禧*. 鈴 木喬**. 小林 広 行*

イオン交換樹脂触媒に関する研究の一環として，邆移金属イオンを主とした金属イオン置換型スルホ ン酸樹脂に淤ける，水，フンモニフ，およびオレフィンの気相吸着を $60 \sim 130^{\circ} \mathrm{C}$ の範囲で測定した。そ の結果，まず前処理の効果として，吸着活性は加熱排気による脱水とともに出現すること，吸着量は ブタジェンく水くアンモニア と塩基性の強いるのほど大きく，また樹脂上の金属イオンの電気陰性度 と強い相関関保がみられたことから，この種の吸着は金属イオンの酸性に起因することを明らかにし た。また，3d-登移金属イオンで系統的に置換した樹脂触媒に扣ける各種の吸着量，アンモニフ吸着熱， 水の浸潤熱の湘定結果は $\mathrm{Mn}^{2+}<\mathrm{Co}^{2+}, \mathrm{Ni}^{2+}, \mathrm{Cu}^{2+}>\mathrm{Zn}^{2+}$ の序列となり, 結晶場安定化エネルギーの 寄与が推察された。また，単位金属イオンあたりのアンモニアとブテンの吸着量が樹脂上金属イオン漕 度の增加とともに急増することに関連して吸着サイトの性質について考察した。

\section{1 緒 震}

イオン交換樹脂の触媒作用飞関する研究は, 従来から主として 液相系に打けるブロトン酸型樹脂を中心に行なわれてきている が1)，樹脂上金属イオンの触媒作用関する系統的研究は，無機 の金属イオン交換体であるゼオライト触媒2)などにくらべて比較 的少ない。著者らは，金属イオン澄換型イオン交換樹脂が，一種 のイオン一高分子錯体であるとの観点から，これら樹脂触媒上の 金属イオンの触媒作用を均一系との対比をる含めて研究を進めて きたの。

本報では，スキレンージビニルベンゼン共重合体を榯脂基体と ナるスルホン酸樹脂上の金属イオンへの気相からの各種の吸着を 㹸定し, 吸着活性と金属イオン種, および金属イオン涨度との関 連を中心に検討を加之，触媒作用を理解する上での基濋的绩報を 得ること䀧的とした。

\section{2 実検}

\section{1 踝媒調慗}

スルホン酸型樹脂として市販の Amberlyst-15 を用い,ブト ンを除くため常法にしたがい、まず $\mathrm{Na}$ 型（以下 $\mathrm{AMNa}$ と略記 する）としたのち，既報》の方法と同様に，硝酸塩水溶液を用い

* 千葉大学工学部, 280 千葉市弥生町

** 山梨大学工学部, 400 甲府市武田

1） a ) 垣花秀武, 成田耕三糟藷, 関得一郎, “イオン交换”, 広川書店 (1960) p. 133.

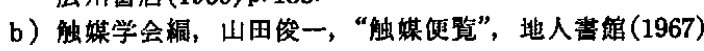
p.727.

2) “Molecular Sieve Zeolites", I, II, Am. Chem. Soc. (1971).

3) a) T. Uematsu, K. Tsukada, M. Fujishima, H. Hashimoto, J. Catal., 32, 69(1974).

b) 相川正樹, 塚田 楛, 上松敬藻, 橋本栄久, 日本化学 会第 30 品季年会発表，4B14(1974) など.
て目的の金属イオン簤換型（以下 AMNaM と略記する）とした。 金属イオンMへの置換量恃置换前後の溶液中の金属イオン量をキ レート滴定で求めて算出し，また対陰イオン $\left(-\mathrm{SO}_{8}{ }^{-}\right)$量の尺度 としてのイオン交奥容量は AMNa の酸一塩基滴定により決定し た。これらの実澌值は表 1 に示す。イオン交換後の触某は, $90^{\circ} \mathrm{C}$ で3 日間乾嬠し, デシケーター中に保存した。各触媒試料の重量 基準はすへてこの状態の䩐燥澍脂とし，イオン交換率は，イオン 交換にとるなら重量变化を補正した上，交換前の $\mathrm{AMNa}$ 蚛媒を 交換容量の基舫とした。

\section{2 吸普澌定}

湮則として, 石英コイルン゙ランス（感度 $6.54 \mathrm{mg} / \mathrm{mm}$, 最大負 荷 $2 \mathrm{~g}$ ）を用いたが，吸着量の少ないブタジェン暖着の澌定には， 定容系に和ける圧力亲化を観測する方法を用いた。試料の前処理

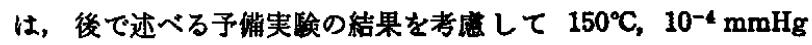
以下で排気とし，佰量化した俌からの重量増，また恃圧力㚆化を 求めて曼着量を算出した。

\section{3 湜淍熱洞定}

前処理として， $110^{\circ} \mathrm{C} ， 5$ 時間加熱排気した試料をフンブルに

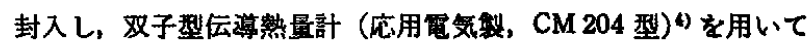
浸潤熱を測定しだ。武料は完全置换型の Amberlyst (AMM) 系 樹脂と，同じくダイヤイオン (HPK-M) 系樹脂を用い，椡定温 度は $25^{\circ} \mathrm{C}$, 溶媒は水である。

\section{3 結 果と考察}

\section{1 前处理排気温度の脱水への影新}

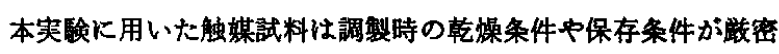
に同一ではあり得ないため, 出発試料の状態を統一するために, 加熱排気にさき立ち，窒温で亘量化するまで排気した。

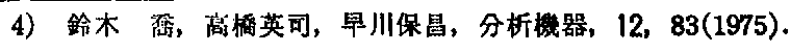


Table 1 Ion-exchange capacity and the fraction of cation-exchanged (AMNaM series)

\begin{tabular}{cccc}
$\begin{array}{c}\text { Catalyst } \\
\text { form }\end{array}$ & $\begin{array}{c}\text { Capacity } \\
\text { (meq/g-cat.) }\end{array}$ & $\begin{array}{c}\text { Fraction of } \\
(\text { eq- } \%)\end{array}$ & $\begin{array}{c}\text { Valence } \\
\text { of } M\end{array}$ \\
\hline AMNa & 3.77 & - & - \\
AMNaCa & 3.80 & 69.6 & 2 \\
AMNaAl & 3.93 & 75.6 & 3 \\
AMNaFe & 3.80 & 76.5 & 3 \\
AMNaTh & 3.33 & 100 & 4 \\
AMNaMn & 3.73 & 67.4 & 2 \\
AMNaCo & 3.71 & 64.0 & 2 \\
AMNaNi & 3.72 & 61.8 & 2 \\
AMNaCu & 3.69 & 64.8 & 2 \\
AMNaZn & 3.69 & 62.6 & 2 \\
AMNaBi & 3.16 & 69.3 & 3
\end{tabular}

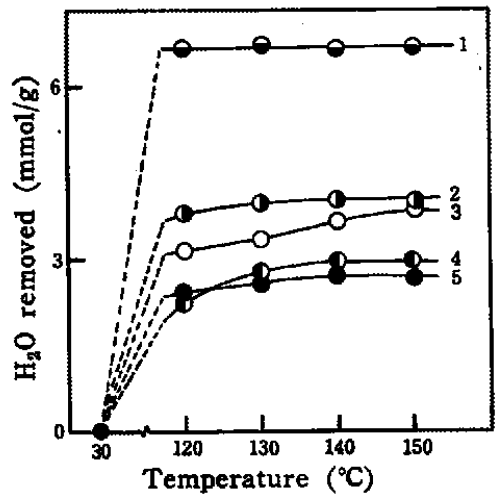

Fig. 1 Dehydration by evacuation at high temperatures

The samples were pre-evacuated completely at room temperature.

1: AMNaAl, $2:$ AMNaFe, 3: AMNaCa,

4: AMNaTh, $5:$ AMNa

この亘量化した試料を基楛として，以後段階的に逐次界温し， 各温度で佰量化するまで加熱排気した場合の重量減少の結果を図 1 に示す。一般にこの種の高檽かけ度の MR（巨大継状構造）型 のスルホン酸樹脂では，酎熱性のるっとす贫る $\mathrm{H}$ 型樹脂です 150 ${ }^{\circ} \mathrm{C}$ までの加熱排気で脱スルホン酸中分解はほとんど起こらな いことが交换容量や触媒活性の変化から確諗されているので， 图に示す重量減少仕すべて眖水に基つくものであるとしてよい。

まず，室温排気による脱水最 $(\mathrm{mmol} / \mathrm{g})$ は, AMNaTh : 2.6, AMNaFe : 8. 9, AMNaAl :0.80,AMNaCa : 5.1, AMNa $: 4.8$ と試料による盖がいちじるしかったが，上に述べたようにこれ は金属イオンの種頼のみ依存するとはいえないために定量的比 㜞は難かしい。さらK加熱排気にとるなら晛本は室温排気で脱水 量の小さかっった AMNaAl を含めて，おおむね $130^{\circ} \mathrm{C}$ までの排文

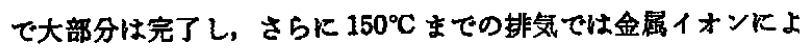
る差はあるすののその脱水量はわずかであることがわかる。一方， $150^{\circ} \mathrm{C}$ で排気した金属イオン庴䐿型およびH型樹脂でブテン異性 化反応にとるなら重水秦の触媒からの取り込みがあることから゙， $150^{\circ} \mathrm{C}$ の排気後るなお一部のヒドロキシル基（あるい叫着水） がれらの榯脂艓上飞存在することが明らかである。以上の結 果から、きわめて現象的にではあるが、これらの触媒上の水を,

5）上松敬㼛，棰本栄久，未発表データ.
（1）室温排気で脱水するすの，（2） $150^{\circ} \mathrm{C}$ までの排気で䟚本 するすの，（3）同しく加熱排気後すな扮残存するすの，に形式 的に分類することができる（1）には，おるに粒界クラック， 㩐 (channe1) 内や細孔内の㖟藏水中物理吸着水 ${ }^{6)},(2)$ に性。 に第一水和殻の直接に対陰イオンや富能基に配位した配位水で化 学吸着的性格の強いすの，(3)はとくに強い分子状の喛着水また は解㕍吸着したヒドロキシル基が主であるらと推剆されるが，こ の区分は明確でない。従来，低橋かけ度のスルホン酸樹脂に利け る水和状態に関しては液中または適度な相姝湿度下で検討され、 䉓解質溶液との対比で諭議されてきた。Glueckauf らクはブロト ンまたは金属イオンの水和数を吸着畐から求めて，一般にッ口 ゲン化物水溶液中の場合と大差がないとし，Zundel ら゙)はH型で 水素結合したトリ〜テトラフクフ錯体を IR の観測から指摘し、 Cohen 5》は $\mathrm{Cu}$-翼換型ではへキサフクア錯体, $\left[\mathrm{Cu}\left(\mathrm{H}_{2} \mathrm{O}\right)_{8}\right]^{2+}$ を形成していることを ESR の結果から報告している。なお，MR 型樹脂に関する報告例はきわめて少ない。

これらのデータを基脴にして，本実跧に和ける眖水量を検討し てみる。用いた武料の交換容量は $3.3 \sim 3.9 \mathrm{meq} / \mathrm{g}$ であり,これ は官能基の数に相当する。一方，保存状態から $150^{\circ} \mathrm{C}$ 排第までの 脱水量 (mmol/g) 仕 5.6 (AMNaTh), 12.9 (AMNaFe) とい ナ゙れるスルホン酸基の数よりる多いことを示している。AMNaFe に関して, ゲル型樹脂での $\left(-\mathrm{SO}_{8}{ }^{-}\right)$への水和数 ${ }^{7)} 1$ と, $\mathrm{Na}^{+}$, $\mathrm{Fe}^{3+}$ への希薄水溶液での水和数 ${ }^{10)} 4,6$ をそれぞれあてはめて評 洒すると，その含水量は $13.2 \mathrm{mmol} / \mathrm{g}(23.7 \mathrm{wt} \%)$ 飞相当する。 この結果は, 上記の $150^{\circ} \mathrm{C}$ まで総脱水量飞匹敵するすのであり， 少なくとる $\mathrm{AMNaFe}$ に沙, 希薄溶液中の水和数に相当する水が 存在していたことを示唂する。

一般に樹脂基体のスッレンージビニルベンゼン共重合体への本 の吸着情弱く，官能基中酸性の強い金属イオンの導入によって曼 水力が增加することが知られているほか，この程度の交換容量の スルホン酸樹脂での平均ブロトン間距離が $8 \mathrm{~A}$ 程度とされている

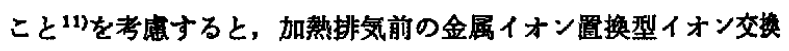
樹脂上の水は，その大部分が直接金属イオンK配位しているるの と推定される。また，水和金属イオンの加本分解しやすいイオン に置換した場合，たとえば，AMNaThなどでは，イオン交换の

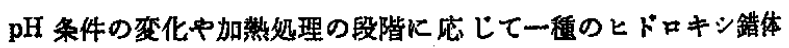
$\left(\mathrm{RSO}_{\mathrm{g}}{ }^{-}\right)_{m} \mathrm{M}^{n+}(\mathrm{OH})_{n-m}{ }^{-} \cdot\left(\mathrm{H}_{2} \mathrm{O}\right)$ を形成子る可能性る強く，その ために脱水過程は単緦でなく，また完全な脱水，脱とドロキシル 基が困難になることが予測される。事実，AMNaTh などの 150 ${ }^{\circ} \mathrm{C}$ までの脱水量は明らかに少ない。

なお，澍脂上金属イオンの水和状態およびその脱水過程の詳編 は, 各温度での吸着最の測定, 昇温脱離の観測のはか, 金属イオ ンの種類によっては，ESR，メスバウアー，NMR などの分光学

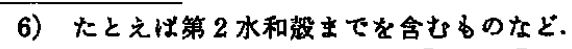

7) E. Glueckauf, G. P. Kitt, Proc. $R$. Soc. London, A 214, 207 (1951); A 228, 322(1955).

8) G.Zundell, H. Noller, G. M. Schwab, Electrochem., 66 , 129(1962).

9) C. H. Wirguin, R. Cohen, J. Phys. Chem., 71, 2556 (1965).

10) C. Glidwell, Inorg. Chim. Acta, 15，85(1975); 日本 化学会編, 化学総説, “イオンと溶媒”, No. 11(1976).

11) H.G. Gregor, M. Frederik, Ann. N.Y. Acad. Sci., 57, 87 (1958). 


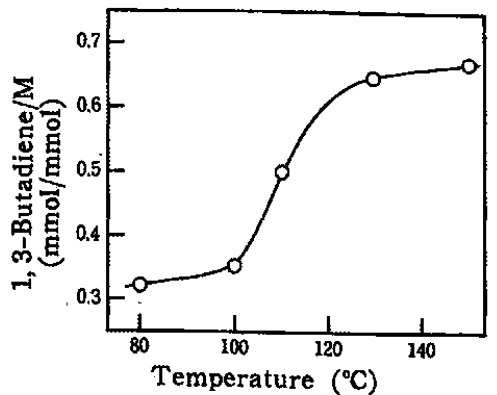

Fig. 2 Effect of pre-evacuation on the adsorption of 1,3-butadiene

Sumple : AMNaFe (Fe ${ }^{3+}$ content $: 76.5$ eq-\%)

Pre-evacuation : $2 \mathrm{hrs}$ at each temperature. Adsorption -

Temperature : $60^{\circ} \mathrm{C}$, Pressure : $100 \mathrm{mmHg}$

的手段によっての解明が可能であろら。

\section{2 加整排気による吸暗活性の变化}

AMNaFe 触媒の前処理排気温度を変えた場合の 1, 3-ブタジェ ンの吸着量の変化を图 2 に示した。これから， $80^{\circ} \mathrm{C}$ 付近の加熱 帮気ですでに一部の吸着サイトが出現していること、100 $の$ の高 温排気によっていちしるしく㖟着活性か增大し， $130^{\circ} \mathrm{C}$ 以上では， 性定常活性を示すことがかかる。この結果は，因1飞福ける脱 水上よる娍量か， $130^{\circ} \mathrm{C}$ の加熱排気で恃完了するといら結果と 対応すると考えられる。すなるち，約 $80^{\circ} \mathrm{C}$ 以上で排気した榯脂

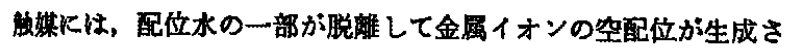
れはじめ，130 $\mathrm{C}$ 以上ではとの大部分が脱離してブタジニンなど の吸着サイトが形成されたと推定される。なおこの結果と耐熱性 を考虑して前処理を $150^{\circ} \mathrm{C}$ 排気とした。

\section{3 水の股着}

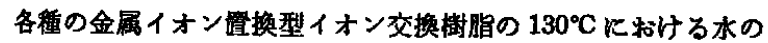
是着等温線を図 3 に示す。これから，AMNaCu触媒を除いて， いずれも水蒸気分圧 $2.5 \mathrm{mmHg}$ 以上では平衡吸着量は增加せず， 見かけ上鳃和していると見られること，さらにこの館和吸着量は 澄換した金属イオンの種類炕強く依存していることが明らかであ

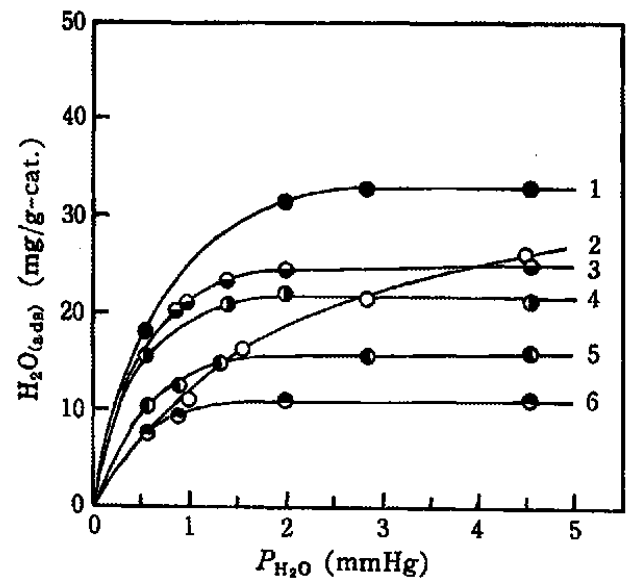

Fig. 3 Isotherms for water adsorption

Pre-evacuation: $150^{\circ} \mathrm{C}$ for $3 \mathrm{hrs}$, Adsorption : $130^{\circ} \mathrm{C}$ 1: AMNa, 2:AMNaCu, 3:AMNaCo, 4:AMNaNi, $5: \mathrm{AMNaZ}_{\mathrm{n}}, 6: \mathrm{AMNaMn}$
る。薣脂基体への水の四着はきわめて弱く，この実臨条件下では 起こらないこと，金属イオン置換型のらち吸着量のきわめて少な いあのるあることから，対陰イオンへの吸着は無視でると考え られる。しかるに，樹脂上の $\mathrm{Na}^{+}$への呂着は，四から無視できな いことが明らかであるので，一般に $\mathrm{AMNaM}$ 上の $\mathrm{Na}^{+}$への曼 着量は $\mathrm{AMNa}$ 上の $\mathrm{Na}^{+}$への䍔着と同じ割合で起こるすのと仮 定した。この值を補正したのち，湗脂上金属イオンMの単位量あ たりの吸着量を算出したところ $\mathrm{H}_{2} \mathrm{O} / \mathrm{M}<1$ となった(图 6,7)。 この值は十分な水の存在下でスルホン酸樹脂に战ける鍮イオン の水和錯体か， $\left[\mathrm{Cu}\left(\mathrm{H}_{2} \mathrm{O}\right)_{6}\right]^{2+}$ となっており, 脱水処理によって, $\left[\mathrm{Cu}\left(\mathrm{H}_{2} \mathrm{O}\right)_{4}\right]^{2+}$ を経由于るといら報告早12) 中低棈加け度 $(0.5 \%$ シ ビニルベンゼン）㯖脂上の金属イオンに対する水和数が室温付近 て., $\mathrm{Na}^{+}: 2.0, \mathrm{Li}^{+}: 3.3, \mathrm{Mg}^{2+}: 5.1, \mathrm{Zn}^{2+}: 5.3, \mathrm{Al}^{1+}: 11.9$, $\mathrm{La}^{+}: 7.5$ などといら報告》とくらへで明らか水少ない。また，゙゙ ル型のスルホン酸榯脂 (Amberlite IR-120) を透移金属イオン

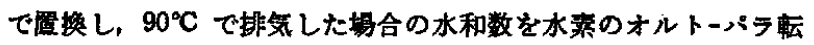
換反応によって求めた結果では，いずれす1.7 2.5 と報告され

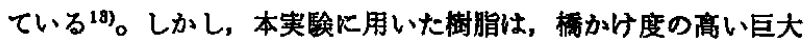
網状構造のるのであり, 吸着温度が娜点よりかなり高いととを考 虑すると矛盾はないるのと思われる。

H型スルホン酸樹脂に和ける室温付近の IR の観测では, 隣接 するスルホン酸基同志が办素結合を通して会合錯体を形成してい

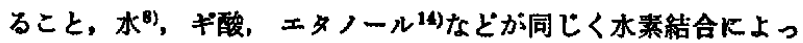
て襩数のスルホン酸基上飞キレート型錯体を形成し得ることが確 認されている。金属イオン圈換型樹脂触媒の場合るこの可能性は あるが，本実酫の条件下では，温度，平衙圧，および観测された 吸着量の $\mathrm{H}_{2} \mathrm{O} / \mathrm{M}$ が小さいことなどを考虑すると，むしろ単純に 水分子として, あるいは一部分解してとドロキシル基として, 直 接金属イオンに配位，吸着していると考える方が妥当であろら。

\section{4 アンモニアの吸着}

$130^{\circ} \mathrm{C}$ に括けるアンモニアの吸着等温線を四 4 亿示す。この实

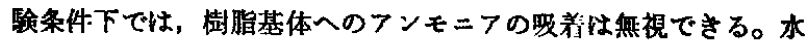

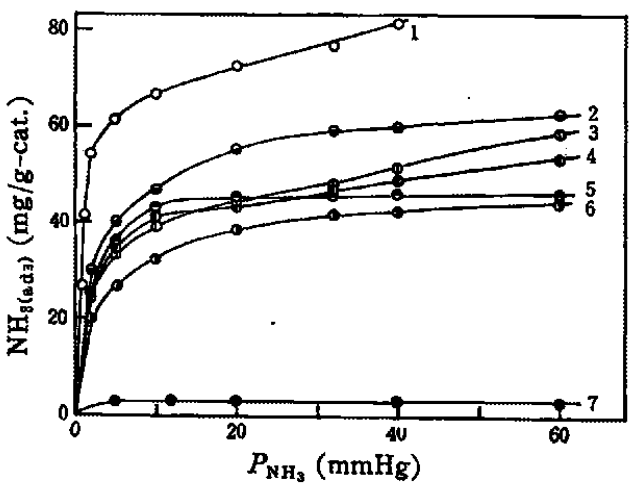

Fig. 4 Isotherm for ammonia adsorption Pre-evacuation : $150^{\circ} \mathrm{C}$ for $3 \mathrm{hrs}$, Adsorption : $130^{\circ} \mathrm{C}$ 1: $\mathrm{AMNaCu}, 2: A M N a C o, 3: A M N a F e, 4: A M N a Z n$, $5: A M N a N i, 6:$ AMNaMn, $7:$ AMNa

12) G. Zundel, A. Murr, Z. Phys. Chem., 54, 59(1967).

13) Y. Tezuka, I. Kanesaka, K. Toyooka, T. Takeuchi, $Z$. Phys. Chem., N. F., 80, 210(1972).

14) R. Thorton, B. C. Gates, 5 th Intern. Congr, on Catal., 20-1 (1972); J. Catal., 34, 275(1974). 


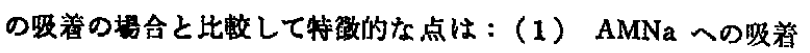
量恃他の金属イオン置換型とくらべて相対的化小さいこと，(2） $A M N a M$ 型への吸着量が一般に水の揚合より大きく、 $\mathrm{NH}_{8} / \mathrm{M}>1$ であること（3）金属イオンの種䒜によっては，高温で吸着罪 が大きいのにるかかからず的の䅡向がな扰見られないこと、で

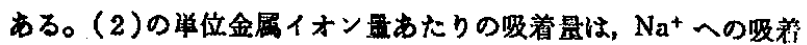
量を办の埸合と同棣に補正した做であるので，得られた絬果（図 4,5）は，值揬金属イオンk配位明著しているフンそニアの平均 数である。フンモニフの貶位数が平衡圧 $5 \mathrm{mmHg}$ 以下ですでに 1 を越えるすのが多いことから，水との呂着量の差は気相分圧の 相違によるのではなく，睎着力の差によるるのである。フンモ二 フの吸着量が大をく， $\mathrm{NH}_{8} / \mathrm{M}>1$ となった原因は，単に塩基性が

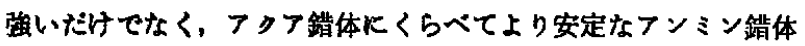
$\left(\mathrm{R}-\mathrm{SO}_{3}{ }^{-}\right)_{n} \mathrm{M}^{n+}\left(\mathrm{NH}_{8}\right)_{m}{ }^{\mathrm{lb}}$ 形成されたためであろう。

なお，昅着等温線は吸着最の小さい颃城ですでに Langmuir 式に道合せず，目位したフンモニフ分子間または膦接基との相百 作用のあることが示唆される。

\section{5 㨽脂上金属イオン流度の影翌}

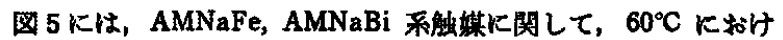
るフンモニフおよび 1-ブテンの鱂着に対する金属イオン满度の 榡を算した。AMNa に対する吸着は少ないので、いずれる金 屈イオン, $\mathrm{Fe}^{9+}, \mathrm{Bi}^{9+}$ への英媇的な吸着であるとみなせる。これ らの金属イオンの樶着サイトが完全に独立で，均一禾における金 蜀イオンの場合と同棣にその活性が等しく，かつ誘起的不鸤一性

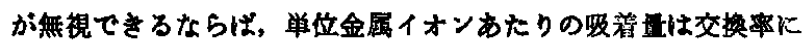
佒存せナ゙一定のはずである。図 5 の結果住これに対して，樹脂上 金属イオン溒度の增加が吸着员の相乗的增大をるたらすことを示 しており，吸着分子間または隣接吸着サイト間の相互作用の存在 广ることが示唆される。イオン交換樹脂上のスルホン酸基のブロ トンまたは圈換金属イオンの活性がイオン交換に関しては均一 であるのにるかかわらず, 触某活性に関しては不均一性を示睃す

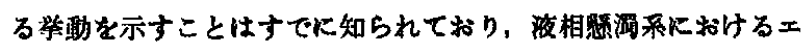

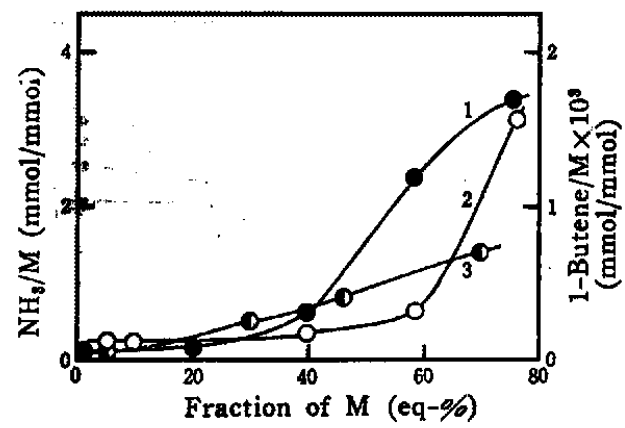

Fig. 5 Influence of the cation concentration on the adsorption of ammonia and 1-butene

Pre-evacuation : $150^{\circ} \mathrm{C}$, for $3 \mathrm{hrs}$

Adsorption-

Temperature : $60^{\circ} \mathrm{C}$, Pressure : $100 \mathrm{mmHg}$

$1: \mathrm{NH}_{3}$ on $\mathrm{AMNaFe}$ series

2: 1-Butene on AMNaFe series

$3: \mathrm{NH}_{3}$ on $\mathrm{AMNaBi}$ series

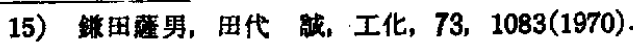

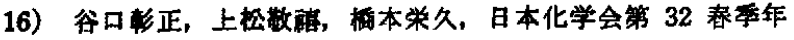
会発表，3K38(1975). ステル加水分解に和ける金属イオンとブロトンロb)10)，同じくェ タノール分佩におけるプロトン漴度 ${ }^{17}$ の增加は访位イオンあたり の活性の減少を示し，気相不均一性におけるブテン異性化反応て

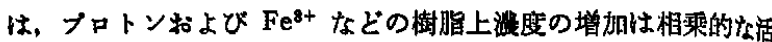

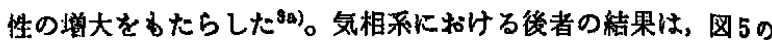
吸着量の变化の举敌と一致しておか，ブテン異性化活性の增大の 主因は，その反応中閔体の急激な璔加に上るるのであることを示 唆している。

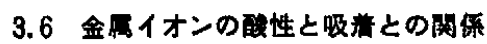

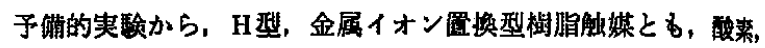
水来、二酸化岸素などの暧着は起こらないことを確認した。一方， 水，フンモニフ，オレフィンなど塩基と考光られるるのに対して 強い吸着能を示し，AMNaFe Kおける吸着昷の大きさは フン

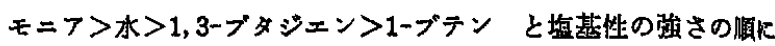
一致し，一種の酸一塩基反応であることがらかがわれた。

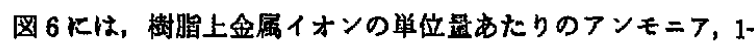
3ーブタジンの平衡吸着量と水の铇和吸着罪を酸性の一つの尺度 である金属イオンの奄気䧔性度 ${ }^{18)}$ に対して示したるのである。な

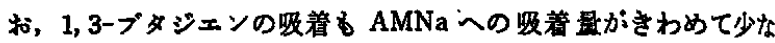
いことから，樹脂基体への吸着俚焦視できるのですべて活性な金 属イオンへの圌着と考えてよい。この結果は、いずれる明らかに 昨着が金属イオンの酸性泓く依存していることを示するのと考 えられる。な持樹脂上の $\mathrm{Fe}^{8+} へ$ へンンモニフの四着量が予想よ ク小さな值であるが，Fe

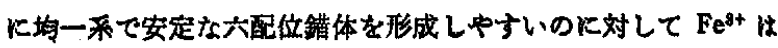

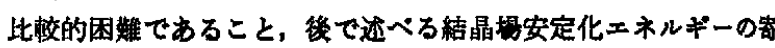
与のない $3 d^{6}$ 蕞造であることに関連していると思われる。

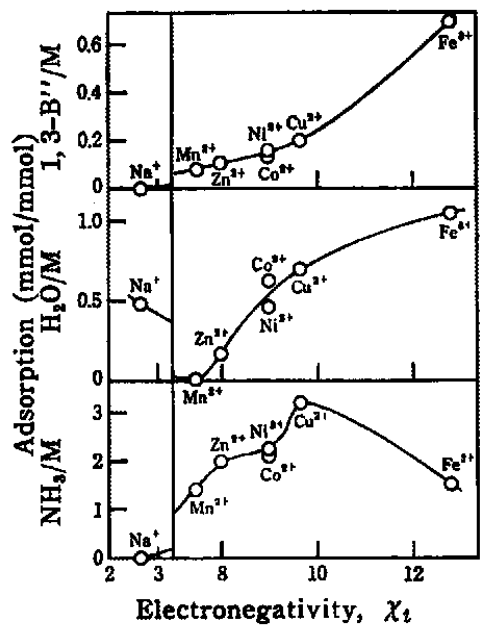

Fig. 6 Activity for adsorption vs. electronegativity of cation on the resin

Pre-evacuation : $150^{\circ} \mathrm{C}$ for $3 \mathrm{hrs}$ Adsorption-

\begin{tabular}{|c|c|c|}
\hline & $\begin{array}{c}\text { Temperature } \\
\left({ }^{\circ} \mathrm{C}\right)\end{array}$ & $\begin{array}{l}\text { Pressure } \\
\text { (mmHg) }\end{array}$ \\
\hline 3-Butadiene & 60 & 100 \\
\hline $\mathrm{H}_{2} \mathrm{O}$ & 130 & 4.58 \\
\hline $\mathrm{NH}_{\mathrm{g}}$ & 130 & 10 \\
\hline
\end{tabular}

17) B.C. Gates, L. N. Johanson, J. Catal., 14, 69(1969).

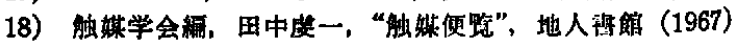
p. 752 . 


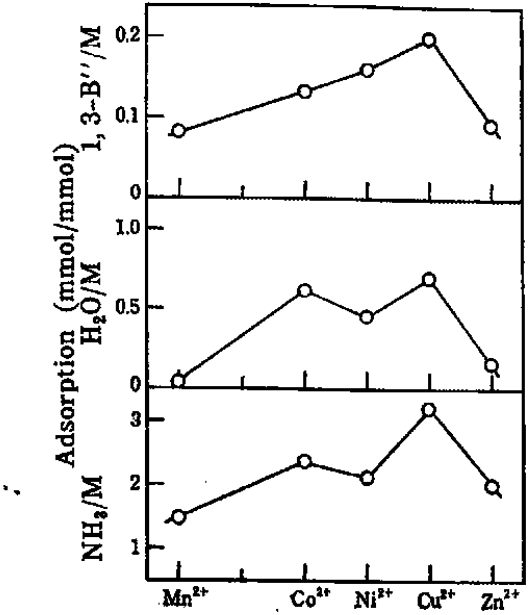

Fig. 7 Adsorption over $3 d$-series transition metal cation on the resin

Pre-evacuation: $150^{\circ} \mathrm{C}$ for $3 \mathrm{hrs}$

Temperature and pressure for adsorption : See Fig. 6

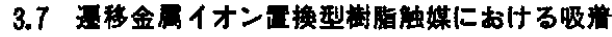

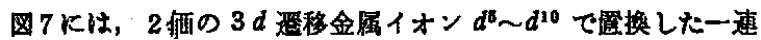
の AMNaM 型船媒におけるアンモニア, 水, ブタジェンの吸着 量を示した。樹脂學体への吸着は然視できるほど少なく、ナトリ ウムイオンへの四着は補正してあるので、これらの値は值接金属 イオンに配位した平均吸着分子数に相当する。この結果から金属 イオンあたりの曼着艘は、 いずれる $\mathrm{Mn}^{2+}\left(d^{6}\right)<\mathrm{Co}^{2+}\left(d^{7}\right), \mathrm{Ni}^{2+}$ $\left(d^{8}\right), \mathrm{Cu}^{2+}\left(d^{9}\right)>\mathrm{Zn}^{2+}\left(d^{10}\right)$ の順に变化しており，均一系におけ る金属イオンのアンミン錯体やキレート錯体の生成定数、水和金

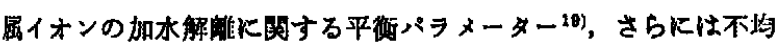
一系における金属酸化物での触媒活性に関する序列を示す，いわ ゆる, Dowden パターン20)と類似の㑯向を示すことがかかる。樹 脂上金属イオンの場合, 均一系での錯体形成の埼合と買なり，そ

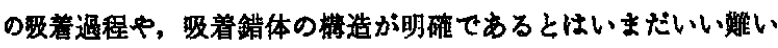
が，得られた結果は同一条件下での平均吸着量であることから， 吸着錯体形成に网する弜衡を少なくとす相対的に反映したるのて めると見ることができる。

この点K関して、気相における塩基の吸着堑拥定，および液相

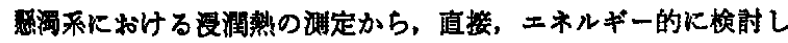
た結果を図 8 に示す。前者は，120 130 $\mathrm{C}$ て吸着等温線から求 めた $\mathrm{NH}_{3} / \mathrm{M}=1$ における吸着愁であるが, $d_{5}, d_{10}$ の $\mathrm{Mn}^{2+}, \mathrm{Zn}^{2+}$ では小さく, $d_{7} \sim d_{0}$ の $\mathrm{Co}^{2+}, \mathrm{Ni}^{2+}, \mathrm{Cu}^{2+}$ で明らかに大きな値と なった。また水の浸润熱においてる，樹脂基体の異なる二系列の 粈媒系列で，平行的な類似の序列 $\mathrm{Mn}^{2+}<\mathrm{Co}^{2+}<\mathrm{Ni}^{2+}>\mathrm{Cu}^{2+}>$

19) F. Basolo, R.G. Pearson, "Mechanisms of Inorganic Reactions", John Wiley and Sons, N. Y. (1958) p. 34.

20) D. A. Dowden, Catal. Rev., 5, 1(1971).

21） B. N. Figgs 著, 山田祥一郎訳, “配位子堨理諭”，南江堂 (1969).

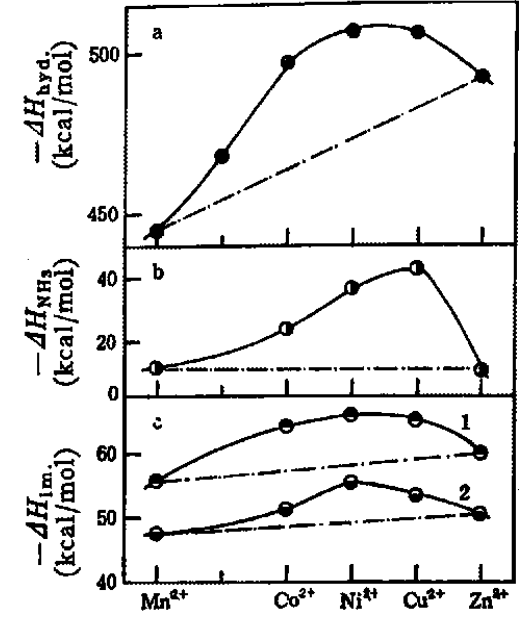

Fig. 8 Heat of hydration, adsorption, and immersion on $3 d$-transtion metal cations

Pre-evacuation : $110^{\circ} \mathrm{C}$ for 5 hrs

a : Heat of hydration, Temperature $: 25^{\circ} \mathrm{C}$, See ref. 19).

b : Heat of adsorption for $\mathrm{NH}_{3}$ (AMNaM series),

Temperature : $120 \sim 130^{\circ} \mathrm{C}$ at $\mathrm{NH}_{3} / \mathrm{M}=1$.

c : Heat of immersion for $\mathrm{H}_{2} \mathrm{O}$, Temperature : $25^{\circ} \mathrm{C}$.

$1:$ HPK-M series, $2:$ AMM series

Zn $\mathrm{n}^{2+}$ の特徽的な㑯向がみられた。目能基を同じとする二系列で

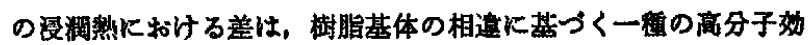
果であると思われる。これらの結果から，図7で锶澌された吸着 量の共通したパターンはニネルギー的にす確認され，暖着錹体ま

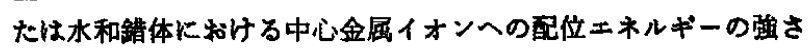
を反映しているといえる。

一般に外部電子の遮蔽好果の少ない $3 d$-遥移金属イオンにおけ

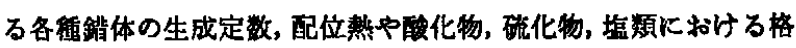
子ェネルギーなど各稞の平衡バラメーターに网して，共通して上 記の序列と類似のパターンが現われることが知られている ${ }^{10221) 。 ~}$ これらの結果梳，酸化物表面における触媒活性に関するDowden パターンを含めて，周囲の各種配位子が中心金属イオンの $3 d$ 乾

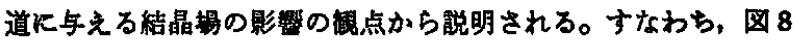
a は気相における金属イオンの水和熱を各種の热力学データから 算出した結果であるが，この举䡃は，鵘結晶勚に和ける六配位八 面体型錯体に和ける結晶揚安定化エネルギー (Dq 単位) が $d_{8} \sim$ $d_{10}$ まで，0，4，8，12，6，0 と变化するバターンに一政してお り, 結晶场安定化エネルギーの寄与として理解されている19)。 お， $\mathrm{Mn}^{2+}$ と $\mathrm{Zn}^{2+}$ を結ぶ鎖線は，この㟢与分を補正した剒合の 電気陰性度の变化によるとする仮想值である。

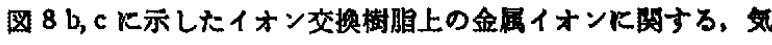

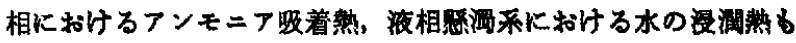
共通してこのパターンに類似した挙䵢を示すことから，結晶场の 影管があるるのと推定される。 


\section{Adsorption of Water, Ammonia and Olefins on Cation-Exchanged lon-Exchange Resins}

Takayoshi Uematsu*, Takashi Suzukı** and Hiroyuki Kobayashi*

* Department of Synthetic Chemistry, Faculty of Engineering,

Chiba University; Yayoi-cho, Chiba-shi 280 Japan

** Department of Applied Chemistry, Faculty of Engineering, Yamanashi University; Kohfu-shi 400 Japan

The adsorption of $\mathrm{NH}_{3}, \mathrm{H}_{2} \mathrm{O}, 1$-butene, and 1,3-butadiene on cation-exchanged sulfonate resins was studied at $60 \sim 130^{\circ} \mathrm{C}$. The water coordinated with the cation and the counter anion of the resin was removed by pre-evacuation above $130^{\circ} \mathrm{C}$ (Fig. 1) and the adsorption of $1,3-$ butadiene on $\mathrm{Fe}$ (III)-exchanged resin was remarkably enhanced by this pretreatment (Fig. 2). The amount of adsorption generally increased with the basisity of the adsorbate : 1 -butene $<1$, 3-butadiene $<\mathrm{H}_{2} \mathrm{O}<\mathrm{NH}_{3}$, and strongly depended on the electronegativity of the exchanged cation (Fig. 6). The fact that the amount of adsorption per unit amount of cation increased with the increase in the cation concentration on the resin indicates that the activity to the cation site is not uniform (Fig. 5). As for a series of $3 d$-transition metal cation-exchanged resin, the activity for the adsorption of $\mathrm{NH}_{3}, 1,3$-butadiene, and $\mathrm{H}_{2} \mathrm{O}$ was in the order, $\mathrm{Mn}^{2+}<\mathrm{Co}^{2+}, \mathrm{Ni}^{2+}$, $\mathrm{Cu}^{2+}>\mathrm{Zn}^{2+}$ (Fig. 7). Similar trends were also found for the heat of $\mathrm{NH}_{3}$ adsorption and for the heat of wetting of water(Fig. 8). 